\title{
Kenen kaupunki?
}

Maaliskuussa Facebook täyttyi vihdoin muustakin kuin koronapostauksista. Joukko Helsingin tulevaisuudesta huolestuneita tutkijoita, arkkitehteja ja aktiiveja julkaisivat pamfletin, jossa kysytään, kenelle ja kenen ehdoilla Helsinkiä tällä hetkellä suunnitellaan. Pamfletti sai valtavan suosion sosiaalisessa mediassa ja moni helsinkiläinen tuntui yhtyvän kirjoittajien huoleen siitä, kuuluuko asukkaiden ääni enää kaupunkisuunnittelussa.

Jos Wienissä esittää kaupunkitutkijoille saman kysymyksen, vastaukseksi saa: Wieniä tehdään nykyään sijoittajien ehdoilla. Vanhat kahvilat sulkevat ovensa, koska eivät kykene maksamaan ulkomaalaisten sijoittajien asettamia vuokria toimitiloista. Ydinkeskustan liiketiloissa maistuu luksus: Gucci, Louis Vuitton, Chanel ja Rolex. Asuntoja rakennetaan yhä enemmän yksityisille vuokranantajille. Toisaalta, Wienin ydinkeskustan kortteleita ei Wienin suuraikana rakennettu yhteisen hyvän näkökulmasta, vaan tavoitteena oli houkutella ja tehdä rahaa. Maineensa erityisesti kohtuuhintaisten asuntojen kaupunkina Wien sai vasta ensimmäisen maailmansodan jälkeen sosiaalidemokraattien ottaessa vallan keisarikunnan raunioista. Aktiivisesta asuinpolitiikasta huolimatta Wienkin kallistuu, kortteli korttelilta. Se vaikuttaa erityisesti maahanmuuttajiin, joita Wienissä on paljon naapurissa sijaitsevista entisistä itäblokin maista. Heillä on myös suhteessa alhaisimmat palkat ja tarjoavat työllään edullisimmat palvelut wieniläisille.

Ulkomaalaistaustaisten asema suunnittelussa hakee myös muotoaan Helsingissä. Kaupunki on esimerkiksi purkamamassa maahanmuuttajayrittäjien tiloja Kontulassa, Itäkeskuksessa ja Malmilla. Joitain vuosia sitten Jussi Pajunen halusi päättää lähiöostareiden pubistumisen lakkauttamalla niiden baarit. Nyt ovat vuorossa vanhojen ostareiden tyhjiä tiloja täyttäneet maahanmuuttajayrittäjät, joiden pitäisi löytää uudet paikat palveluilleen. Kaikki tämä tapahtuu samaan aikaan, kun esikaupunkialueista halutaan tehdä urbaanimpia. Itse asiassa yleiskaavassa jopa visioidaan, että urbaaniuteen kuuluu muun muassa "enemmän kansainvälisyyttä" (Helsingin kaupunkisuunnitteluviraston yleissuunnitteluosaston selvityksiä 2013:13, 2013). Kysymys kuuluu, millaista kansainvälisyyttä?

Itävaltalais- ja maahanmuuttajataustaiset wieniläiset ovat yhdessä alkaneet aktivoitumaan pitääkseen monipuoliset ja edulliset palvelut naapurustossaan. Nykyään turistienkin suosiossa olevan iso markkina-alueen Naschmarktin viereen kaupunki haluaa rakentaa ison kauppahallin. Naschmarkt on vanha markkinapaikka, jonka aikoinaan kiinalaiset maahanmuuttajat ottivat haltuunsa toisen maailmansodan jälkeen ja nimesivät Nashimakiksi. Nykyään 
perinteiset kiinalaiset liikkeet ovat siirtyneet muualle ja markkinapaikalla toimii ravintoloita ja pieniä puoteja, joissa myydään niin Lähi-idän herkkuja kuin perinteisiä itävaltalaisia ruokia. Viikonloppuisin alueelle levittäytyvät viljelijöiden markkinat ja kirpputori. Kauppahallin rakentaminen alueelle on innovaation, kaupunkisuunnittelun ja liikkuvuuden varakaupunginjohtaja Ulli Siman lempilapsi. Hän haluaa tarjota alueen asukkaille mahdollisuuden ostaa itävaltalaisia tuotteita sisätiloissa. Asukkaat vastustavat sekä kauppahallin tavoitteita että koko ylhäältä alaspäin kulkevaa suunnitteluprosessia. Asukkaiden ääni näkyy muun muassa keltaisina banderolleina, jotka roikkuvat ikkunoista alueella, sekä laajana nimenkeräyskampanjana. Ennen kaikkea asukkaat vaativat, että alue pysyisi avoimena julkisena tilana, sillä sellaisia tiloja kasvavassa kaupungissa on yhä vähemmän. Asukkaille riittävät hyvin alueen nykyiset, kansainväliset ja kotimaiset palvelut.

Tässä vuoden 2021 ensimmäisessä numerossa paneudutaan monella eri tapaa siihen, kenellä on oikeus kaupunkiin ja sen suunnitteluun. Johtokunnan palstalla Pekka Normo ja Marja Salmela vetoavat seuran jäseniin, jotta tonttirahastojen vaikutuksesta asuntojen, hintaan, asukkaiden kuluttajaturvaan ja rakennusten tulevaisuuteen alettaisiin julkisesti keskustelemaan. Tonttirahastot ovat pankkien uusi investointituote, jonka kautta on löydetty uusi tapa tehdä voittoa kaupunkiasumisella. Lehden artikkeleissa tutustutaan Helsingin leikkipuistojen kehittymiseen niin rakennetun ympäristön, leikkikenttien arjen ja hyvinvointivaltion näkökulmasta Veera Mollin ja Essi Jouhkin johdolla. Jarre Parkatti puolestaan pohtii Helsingin suunnittelua kehittämällä Bent Flyvbjergin teoriaa kommunikatiivisesta suunnittelusta eteenpäin. Katsauksissa Tommy Lindgren kirjoittaa Kenen kaupunki -pamfletista ja Kaj Nyman puolestaan arvioi aikoinaan suunnittelemaansa Peltosaaren asuinaluetta Riihimäellä. Jenni Kuoppa arvioi kirjan Urban awakenings. Disturbance and enchantment in the industrial cityn melbournelaista "urbaania patikointia", ja Hannu Ruonavaara puolestaan palaa klassikkoarviossaan asumisen tutkimukseen vahvasti vaikuttaneeseen Jim Kemedyn teokseen The Myth of Home-ownership. Private versus public choices in housing tenure.

Wienissä, 20.5.2021

Johanna Lilius

Päätoimittaja

LÄHTEITÄ:

Helsingin kaupunkisuunnitteluvirastonyleissuunnitteluosaston selvityksiä 2013:23 (2013).

https://www.hel.fi/hel2/ksv/julkaisut/yos_2013-23.pdf 